\title{
DETERMINANT FACTORS OF SENIOR TOURISTS’ LENGTH OF STAY
}

\author{
Elisa Alén, Universidad de Vigo \\ Juan Luis Nicolau, Universidad de Alicante \\ Nieves Losada, Universidad de Vigo \\ Trinidad Domínguez, Universidad de Vigo
}

\begin{abstract}
The current tendency to undertake more trips, but of shorter duration, throughout the year, has meant that the tourist industry has started to show greater interest in attracting those market segments that opt for more prolonged stays, as they are especially profitable. One of these segments is that of seniors. Given the aging demographic of the population worldwide, which is particularly noticeable in Spain, the object of this study is to identify the variables that determine the length of stay of Spanish seniors at their destination. The determinant factors of the length of stay by Spanish seniors identified were: age, travel purpose, climate, type of accommodation, group size, trip type and the activities carried out at the destination. This study is a contribution to this field from an empirical point of view, given the scarcity of studies of this type and their eminently descriptive character; as well as from a practical level, with interesting implications for the sector.
\end{abstract}

Keywords: length of stay, Spanish seniors, aging demographic

\section{INTRODUCTION}

Length of stay is a variable of special interest for any tourist destination, given its positive relationship to tourism income (Barros et al., 2010; Martínez-García and Raya, 2008). Tourists who stay at their destination longer visit more attractions and generate more business for the destination than those who stay for a shorter time (Barros and Machado, 2010; Martínez-García and Raya, 2008). Hotels, for their part, maximise profits, reduce fixed costs and maintain high occupation rates as tourists increase the length of their stay (Barros and Machado, 2010; Peypoch et al, 2012). This is also one of the most important variables in a tourist's decision-making process, and therefore it is one of the key aspects in destination planning and management (Alegre and Pou, 2006; Salmasi et al, 2012). However, despite the importance of this variable for tourist destinations, up until now there have been few studies related to the length of stay at the destination, notably: Alegre and Pou, 2003; 2006; Alegre et al, 2011; Barros and Machado, 2010; Barros et al, 2010; Ferrer-Rosell et al, 2014; Fleischer et al, 2011; Gokovali et al, 2007; Grigolon et al, 2014; Martínez-García and Raya, 2008; Meng and Uysal, 2008; 
Nicolau and Más 2006; 2009; Peypoch et al, 2012; Seaton and Palmer, 1997; Salmasi et al, 2012 and Wu and Carson, 2008.

The reduction of the length of the stay at the destination in favour of shorter trips taken more often throughout the year, is one of the tendencies that has characterised the tourism industry in recent years (Alegre and Pou, 2003; Barros and Machado, 2010; Ferrer-Rosell et al, 2014; Fleischer et al, 2011; Gokovali et al, 2007; Salmasi et al, 2012). This tendency has been recently fostered by an increase in business trips and the appearance of low-cost airlines (VV.AA. in Barros and Machado, 2010). Martínez-García and Raya (2008) advised that the reduction in the duration of stay of tourists in Spain involves a reduction in tourist spending, the total expenditure only being offset by an increased flow of visitors. Given the importance for destinations to have long-stay tourism, it is necessary to undertake an in-depth analysis of this variable in order to identify exactly which factors affect the length of stay. This will provide the necessary tools to allow the relevant bodies involved in destination planning and management to attract those travellers who show a greater predisposition to more prolonged stays.

One of the groups that show a greater tendency to make more prolonged stays at destinations are seniors. As they lack certain obligations (work, family) and have more free time to travel, as well as higher discretional income than other groups, they tend to enjoy more prolonged stays at their destinations than other travellers (Alegre and Pou, 2003; Blazey, 1992; Romsa and Blenman, 1989; Nicolau and Más, 2006). Interest in this group’s mobility patterns has increased in recent years as a consequence of the population aging process being experienced on a global scale (Moniruzzaman et al, 2013).

If the population ages globally, in Europe it does so at a precipitous pace. Spain will be one of the countries with the oldest population in Europe in the next few years, to the extent that by 2050, one in every two people in Spain will be 50 years old or over (United Nations, 2013). The UNWTO has estimated that, by 2050, the population above 60 years old will make up more than 2 thousand million international journeys, as opposed to 593 million in 1999 (Patterson, 2006). In 2012 in Spain, 62.1\% of homes comprised of people between 51 and 65 years old made some sort of trip, with foreign visitors older than 64 being those who spent the most on tourism in Spain (IET, 2012a; IET, 2012b).

The demographic aging being experienced globally, basically in the more developed regions, will mean that senior tourism will be considered to be one of the most important markets with the fastest growth in the tourism industry, this segment becoming the 'growth engine' of tourism (Schröder and Widmann, 2007). Cooper et al. (2007), Glover and Prideaux (2009) and Ryan (1995) noted that the aging baby boom generation is one of the most relevant markets in the tourism sector.

The purpose of this study is to identify those variables that influence Spanish senior citizens' length of stay at the destination, given their importance for the tourism industry, since the predictions for the 
next few years indicate that Spain will be one of the countries with the most aging population in the world (United Nations, 2013).

This study intends to make an empirical contribution to the topic of length of stay in destination of the mature Spanish population, given the scant number of existing studies and their eminently descriptive character (Bai et al, 2001; Blazey, 1992; Fleischer and Pizam, 2002; Fleischer and Seiler, 2002; Jang et al, 2003; Lawson, 1991; Oppermann, 1995; Romsa and Blenman, 1989; Wang, 2005 and Wang et al, 2008).

\section{LENGTH OF STAY}

Length of stay, as well as being one of the most important variables of a tourist's decision-making process (Salmasi et al., 2012), is strongly related to the rest of the variables that form part of the tourist experience, such as the type of accommodation used, the destination etc., characterised by their interdependence - in that decisions are not taken independently of other considerations—-, and by their subordination, sometimes to barriers such as those related to financial resources, time, family, etc. (Dellaert et al, 1998). However, despite the fact that various authors have demonstrated the importance of length of stay for tourism-generated income at the destination, few have been interested in identifying the causal factors for this variable (Alegre et al, 2011).

The existing studies have referred to four types of variables that determine travellers' length of stay at destination, namely socio-demographic variables, those related to the life-cycle of the individual, travel motivation and variables related to the trip itself.

\section{Socio-demographic variables}

Age and sex are two recurrent socio-demographic variables in the studies dealing with length of stay at the destination. It is considered that age has a positive relationship with length of stay (Alegre and Pou, 2003; Blazey, 1992; Fleischer and Pizam, 2002; Fleischer and Seiler, 2002; Barros and Machado, 2010; Barros et al, 2010; Martínez-García and Raya, 2008; Meng and Uysal, 2008; Nicolau and Más, 2009; Romsa and Blenman, 1989; Salmasi et al, 2012); although it begins to have a negative relationship when it reaches a certain level, mainly for health reasons (Fleischer and Pizam, 2002; Fleischer and Seiler, 2002). Some of these authors connect the tendency in terms of length of stay amongst the elderly with the individual's work situation. They consider that, once the individual enters retirement, the length of stay at the destination increases with respect to those individuals still active in the work market, given the greater amount of free time available to them (Blazey, 1992; Fleischer and Pizam, 2002; Fleischer and Seiler, 2002; Romsa and Blenman, 1989; Salmasi et al, 2012). As to the 
sex variable, the studies agreed in finding that men tended to take longer trips than women, this trend also being maintained in adulthood (Barros and Machado, 2010; Meng and Uysal, 2008). The following hypotheses are therefore proposed:

H1. Age has a positive relationship to length of stay.

H2. Men tend to do trips with longer stays.

\section{Life cycle}

Cooper et al (2007) indicated that both the propensity to travel and the type of tourist experience are strictly related to the individual's domestic age, which refers to the stage in the life cycle that has been reached. The individual's domestic age explains the differences in terms of types of tourist demand and travel propensity, based on two fundamental factors: time and income available. These two factors are in turn influenced by other factors, such as household structure, the chronological age of the individual and their situation in the job market. Various studies have established a relationship between the individual's life-cycle stage, and trip duration (Grigolon et al, 2014; Lawson, 1991; Oppermann, 1995; Seaton and Palmer, 1997). Therefore, taking into account that, as discussed by Cooper et al (2007), the individual's domestic age is controlled by economic status and available time, and that these characteristics are subjective, the following hypotheses have been formed:

H3. Self-perceived economic status influences the length of stay.

H4. The self-perceived amount of time available influences the length of stay.

\section{Motivation}

The main area of research concerning travel and tourism is based around motivation (Alén et al, 2010). Certain authors have emphasised the presence of two main motivational components, push factors and pull factors. Crompton (1979) indicated that push factors explain the desire to travel, whilst pull factors explain the choice of destination. Dann (in Crompton, 1979) connected push factors to the need to travel, and argued that these factors are conducive to pull factors, which are linked to the choice of destination. Regarding push factors for seniors, despite the fact that trips for holiday purposes make up a large part of the trips taken by this group, other reasons for travel worth mentioning are to visit family and/or friends, and health and work, as travel types with a large potential for this segment of the population. Trips undertaken for visiting family and/or friends are, according to various authors, those preferred by the elderly population (VV.AA. in Lee, 2005). In addition, as mentioned by the UNWTO (2010), health tourism will be one of the most popular types, given the aging demographic, particularly in Europe. Trips taken for work reasons by seniors are also of special interest, taking into 
account the high percentage of the elderly population who travel for this reason with respect to the rest (Blazey, 1992; Collins and Tisdell, 2002).

Various authors agree that a relationship exists between the main motive or reason for the trip-push factors - and the length of stay at the destination (Jang et al, 2003; Lawson, 1991; Seaton and Palmer, 1997; Wang, 2005; Wang et al, 2008). They have specifically noted that in trips made for the purpose of seeing family and/or friends, the average length of stay is higher. This result is basically due to the lack of accommodation costs, which allows the stay at the destination to be prolonged with the same available budget. Consequently, the following hypothesis is proposed:

\section{H5. The main purpose for the trip determines its length}

In terms of pull factors, or appealing attributes of the destination, the most important ones when choosing the destination for seniors have been noted as being: hygiene and cleanliness, security, climate, cost, events and attractions, ease of transport, shopping areas, medical coverage, places of historical/artistic interest, natural attractions/countryside and distance, according to the studies by Baloglu and Uysal (1996), Chen (2009), Huang and Tsai (2003), Jang and Wu (2006), Norman et al (2001), Prayag (2012), Sangpikul (2008), Wang (2005) and Wu (2003).

In the same way as with the main purpose for the journey, it is considered that factors which operate as attributes of the destination determine the length of stay. Barros and Machado (2010) stated that length of stay is positively related to those destinations that are appealing because they are wine producers, have traditions, casinos or appealing natural features. Alegre and Pou (2003), Barros et al (2010) and Nicolau and Más (2009), for their part, found that climate has a positive effect on length of stay. Besides, the preference for economical destinations has been found to promote longer stays (Nicolau and Más, 2009). Therefore, it is considered that:

H6. The appealing attributes of the destination determine the length of stay

\section{Travel characteristics}

The travel characteristics considered to be the most important when it comes to determining length of stay include: the (national/international) destination, type of accommodation, mode of trip (individual/group), type of trip and the activities carried out.

With respect to the destination, it has been found that seniors travel as much nationally as internationally (Litrell et al, 2004; $\mathrm{Wu}, 2003$ ), and that this is related to the length of stay. Wu and Carson (2008) noted that international trips have a positive relationship with length of stay with respect to national trips. It is therefore proposed that: 


\section{H7. The (national/international) destination determines the length of stay}

With regard to the type of accommodation used during the trip, the majority of seniors stay at a hotel, followed by a holiday apartment, family and/or friends' houses, second residence, and, at a lesser rate, country house lodges (Bai et al., 1999; Batra, 2009; Lawson, 1991). Of these five types of tourist accommodation preferred by seniors, holiday apartments contribute to prolonging the length of stay at the destination, according to Martínez-García and Raya (2008) and Salmasi et al (2012). Accommodation at a second residence, as proposed by Nicolau and Más (2006), or in the house of family members and/or friends, according to Lawson (1991), or in free accommodation-either their own or belonging to family members and/or friends—according to Martínez-García and Raya (2008) and Salmasi et al (2012), involves a longer stay. However, staying in a hotel reduces the length of stay in comparison to accommodation in a holiday apartment (Alegre and Pou, 2006). Consequently, the following hypothesis has been formulated:

\section{H8. The type of accommodation determines the length of stay}

There is another variable of special relevance that influences length of stay, that is, the size of the travelling group. Alegre and Pou (2006) estimated that as group size increases, the duration of the trip is reduced, probably due to economic restrictions. Salmasi et al (2012) found that once a certain number of people in a group had been reached, length of stay tended to decrease. Lawson (1991) noted that the average stay at the destination of seniors who travelled alone was longer than the average stay of those who travelled as part of a group. The following is therefore proposed:

\section{H9. The mode of travel (alone/as part of a group) determines the length of stay}

Travel types may be classified as organised trips, commonly known as 'package holidays', escorted or 'guided tours', and individual or 'fully independent travel' (Patterson, 2006). In the Spanish senior tourism market, the most popular are basically: independent travel, package holidays and the trips organised by a public organisation, basically the IMSERSO (Institute for the Elderly and Social Services). Javalgi et al (1992) indicated that package holidays are the seniors' preferred modality as opposed to the non-seniors. According to Patterson (2006), this is due to questions of convenience and security, and they are an alternative to independent travel, especially for those elderly who are single, widowed or divorced. Bai et al (2001) established that a relationship exists between the travel type chosen by seniors and the length of their stay, with those who travel independently having a longer stay than those who choose a package holiday. Therefore, the following is proposed:

H10. Travel type determines the length of stay 
Finally, the following are the main activities carried out by seniors at their destination: shopping, organised day trips, visits to historical or artistic sights, physical and sports activities, going to the cinema or theatre and visiting museums (Bai et al, 2001; Batra, 2009; Lawson, 1991; Litrell et al, 2004; Wang et al, 2008). In addition to the significant economic impact that these activities carried out in the tourist destination have on local economies, they also have a positive relationship to the length of stay. It is considered that the greater the number of activities performed, the longer the stay at the destination (Ferrer-Rosell et al, 2014; Lawson, 1991). The following is therefore proposed:

\section{H11. The activities carried out at the destination determine the length of stay}

\section{METHODOLOGY}

To achieve the aims of this study a quantitative approach was chosen. The questionnaire used in this study was based on the theory discussed above and was divided into two parts. The first consisted of questions about socio-demographic variables—age, sex, employment situation, income and family structure and size, travel experience, education level and purchasing power (source of income and home ownership)—as well as self-perceived factors—-health, economic status and time—, based on the studies by Blazey (1992), Cooper et al (2007), Fleischer and Pizam (2002), Fleischer and Seiler (2002), Meng and Uysal (2008), Romsa and Blenman (1989), Schröder and Widmann (2007), Wang (2005) and $\mathrm{Wu}$ (2003). The second part is comprised of issues related to travel purpose (push factors)—holidays, visits to family and/or friends, health and work—and those about the destination (pull factors) based on the studies of Bai et al (1999), Baloglu and Uysal (1996), Blazey (1992), Chen (2009), Huang and Tsai (2003), Jang et al (2003), Jang and Wu (2006), Lawson (1991), Norman et al (2001), Sangpikul (2008), Wang (2005), Wang et al (2008) and Wu (2003). Finally, issues to do with the trip's characteristics - destination, type of accommodation used, mode (individual/group), type of trip, length of trip and activities carried out at the destination — are almost totally based on the studies by Bai et al (1999), Bai et al (2001), Batra (2009), Javalgi et al (1992), Lawson (1991), Patterson (2006), Wang et al (2008) and Wu (2003).

In order to obtain the data, telephone interviews were conducted with Spanish residents over 55 years old. The cut-off age was basically decided upon for two reasons. The first was that it is the average age used in the studies that deal with the elderly and tourism, as has already been shown in the theoretical framework of this study. Secondly, as argued by Plog (2005), Prideaux et al (2001) and Ramos (2005), it is the baby-boom generation, made up in Spain by those currently aged around 55 years old, which will bring profound changes to the market in general and, according to Cooper et al (2007), to the tourism market in particular. 
In Spain adults over 55 years of age in 2010 made up 27.6\% of the total population, 12,990,731 people (INE, 2010) and, of these, $44.19 \%$ made at least one journey with an overnight stay at the destination in the same year (IET, 2010).

With the aim of obtaining the necessary data to verify the study's hypotheses, a two-stage probability sample was chosen. In the first stage the target population was divided into sub-populationsclusters-, depending on the geographic area of residence, specifically by province. Based on the number of adults over 55 years old by province, and the total number of travellers over 55 years old by Autonomous Community (regional subdivision in Spain), the total number of travellers by province was calculated. Later, the sample size by province proportional to the number of travellers was calculated. Finally, a total of 358 valid questionnaires were obtained, which were then used for the statistical analysis (see Table 1).

Table 1 - Data Sheet

\begin{tabular}{|l|l|}
\hline Universe & Spanish nationals aged 55 and over residing in Spain \\
\hline Geographic location & Spain, 17 autonomous regions, excluding Ceuta and Melilla. \\
\hline Sample size & 358 valid questionnaires \\
\hline Sample error & $\pm 5,2 \%$. Relative maximum difference $11,7 \%$ \\
\hline Confidence level & $95 \% \quad \mathrm{z}=1,96 \quad$ true proportion $=0,44$ \\
\hline Sample design & 2-stage cluster probability sampling \\
\hline
\end{tabular}

\section{Data analysis technique}

The method applied to examine the factors that have an influence on seniors' length of stay is based on the estimation of a count model based on the Negative Binomial distribution. Following the general formulation of the Negative Binomial model, the probability of individual t choosing a number $y_{t}$ of holiday days is given by the expression:

$$
P\left(y_{t}\right)=\frac{\Gamma\left(\alpha^{-1}+y_{t}\right)}{\Gamma\left(\alpha^{-1}\right) \Gamma\left(y_{t}+1\right)}\left(\frac{\alpha^{-1}}{\alpha^{-1}+e^{\sum_{k=1}^{K} \beta_{k} x_{t k}}}\right)^{\alpha^{-1}}\left(\frac{e^{\sum_{k=1}^{K} \beta_{k} x_{t k}}}{\alpha^{-1}+e^{\sum_{k=1}^{K} \beta_{k} x_{t k}}}\right)^{y_{t}} \forall \mathrm{y}_{\mathrm{t}}=\{0,1,2, \ldots\}
$$

where $\Gamma$ represents the Gamma function, $\mathrm{x}_{\mathrm{tk}}$ the characteristic $\mathrm{k}$ of individual $\mathrm{t}$ and $\beta_{\mathrm{k}}$ the parameter which indicates the effect of $\mathrm{x}_{\mathrm{tk}}$ on $\mathrm{P}\left(\mathrm{y}_{\mathrm{t}}\right)$. The parameter $\alpha$ covers the dispersion of the observations, in such a way that $E\left(y_{t}\right)=e^{\sum_{k=1}^{K} \beta_{k} x_{t k}}=\lambda_{t}$ and $V\left(y_{t}\right)=e^{\sum_{k=1}^{K} \beta_{k} x_{t k}}+\alpha \cdot e^{2 \sum_{k=1}^{K} \beta_{k} x_{t k}}=\lambda_{t}+\alpha \cdot \lambda_{t}^{2}$. One way of verifying the validity of the Negative Binomial model as opposed to the Poisson model consists of 
testing the null hypothesis $\alpha=0$. Note that its acceptance would imply that $E\left(y_{t}\right)=V\left(y_{t}\right)$, so that the Poisson model is a particular case of the Negative Binomial when $\alpha=0$ (Gurmu and Trivedi, 1996).

This approximation overcomes the bias problems of the regression analysis arising from the discrete character of the dependent variable (Hellerstein and Mendelsohn, 1993) and the inefficiency problems of the Multinomial Logit Model (Cameron and Trivedi, 1998) when analysing the number of days a tourist spends on holiday. The Multinomial Logit Model has serious disadvantages as a consequence of the consideration of a high number of alternatives $(0,1,2,3, \ldots$ days $)$, which prevents the model from attaining efficient estimations. In fact, Cameron and Trivedi (1998) indicate that alternatives which are rarely chosen should be aggregated in order to obtain an efficient estimation of the Multinomial Logit.

At any rate, the adaptation of the Negative Binomial model to the situation in question requires an additional modification, given that a zero value of the dependent variable has a qualitative meaning which is different from that of other values. Any value above zero indicates the number of days an individual has decided to go on holiday, bearing in mind that the decision to go has already been made; while a value of zero represents the qualitative decision not to go. In these types of situation, it makes sense to concentrate on those observations whose dependent variable is distinct from zero, therefore truncating the distribution of the variable (Greene, 2012). Accordingly, we apply the model based on the Negative Binomial distribution to the sample truncated at zero. Bearing these considerations in mind and following Cameron and Trivedi (1998), the expression which represents the probability of individual t choosing a number yt of days more than zero, takes the following form:

$P\left(y_{t} \mid y_{t}>0\right)=\frac{\Gamma\left(\alpha^{-1}+y_{t}\right)}{\Gamma\left(\alpha^{-1}\right) \Gamma\left(y_{t}+1\right)}\left(\frac{\alpha^{-1}}{\alpha^{-1}+e^{\sum_{k=1}^{K} \beta_{k} x_{t k}}}\right)^{\alpha^{-1}}\left(\frac{e^{\sum_{k=1}^{K} \beta_{k} x_{t k}}}{\alpha^{-1}+e^{\sum_{k=1}^{K} \beta_{k} x_{t k}}}\right)^{y_{t}}\left(\frac{1}{1-\left(1+\alpha \cdot e^{\sum_{k=1}^{K} \beta_{k} x_{t k}}\right)^{\alpha^{-1}}}\right)$ $\forall \mathrm{y}_{\mathrm{t}}=\{1,2, \ldots\}$.

where $\beta_{\mathrm{k}}$ is the parameter which indicates the effect of $\mathrm{x}_{\mathrm{tk}}$ on $\mathrm{P}\left(\mathrm{y}_{\mathrm{t}} \mid \mathrm{y}_{\mathrm{t}}>0\right)$.

The estimation of $\theta\left(\beta_{\mathrm{k}}\right)$ is made by maximum likelihood from the function

$$
\begin{aligned}
& M V(\theta)=\sum_{t=1}^{T}\left\{\sum_{j=0}^{y_{t}-1} \ln \left(j+\alpha^{-1}\right)-\ln \left(y_{t} !\right)-\left(y_{t}+\alpha^{-1}\right) \ln \left(1+\alpha \cdot e^{\sum_{k=1}^{K} \beta_{k} x_{t k}}\right)+\right. \\
& \left.+y_{t} \ln \alpha+y_{t} e^{\sum_{k=1}^{K} \beta_{k} x_{t k}}-\ln \left(1-\left(1+\alpha \cdot e^{\sum_{k=1}^{K} \beta_{k} x_{t k}}\right)^{\alpha^{-1}}\right)\right\}
\end{aligned}
$$




\section{RESULTS AND DISCUSSION}

The average age of those surveyed was 67.2 years old. Of those, the majority were women (56.7\%). Self-perceived health and available time were the greatest self-perceived factors, with an average of 4.14 and 3.87 respectively, whilst available income obtained a lower score, with an average of 3.04.

With regard to motivation, although holiday trips were the major option chosen by this group, it must be noted that they also travelled for other reasons, mainly to visit family and/or friends and, to a lesser degree, for health and work reasons. The majority of the trips were taken inside Spain.

As can be seen in Table 2, the importance given to the destination's attributes varied significantly. The most valued were places of historical or artistic interest, places in nature and climate, whilst those least valued were shopping areas and distance.

With respect to the travel characteristics of the respondents, it was confirmed that there was a clear tendency to use hotel accommodation, and to travel with a partner in the majority of cases, or with family members and friends. There was also a tendency to travel independently, demystifying the relevance of package holidays and organised trips referred to by authors such as Javalgi et al (1992). It was also seen that most of the time was spent visiting places of historic/artistic interest and the least time was spent in doing physical activities.

Table 2- Description of the sample

\begin{tabular}{|c|c|c|}
\hline \multicolumn{2}{|l|}{ Variables } & $\overline{\mathrm{x}}$ ó \% \\
\hline \multicolumn{2}{|l|}{ Age } & 67,2 \\
\hline Gender & $\begin{array}{l}\text { Male (reference alternative) } \\
\text { Female }\end{array}$ & $\begin{array}{l}43,3 \% \\
56,7 \%\end{array}$ \\
\hline \multicolumn{2}{|c|}{ Self-perceived health (1-5 Likert scale) } & 4,14 \\
\hline \multicolumn{2}{|c|}{ Self-perceived economic status (1-5 Likert scale) } & 3,04 \\
\hline \multicolumn{2}{|c|}{ Self-perceived time (1-5 Likert scale) } & 3,87 \\
\hline \multirow{2}{*}{ Destination } & National & $80,6 \%$ \\
\hline & International (reference alternative) & $19,4 \%$ \\
\hline \multirow{4}{*}{ Motivation (\% yes) } & Holiday & $83,5 \%$ \\
\hline & Visiting friends or relatives & $30,7 \%$ \\
\hline & Health & $4,5 \%$ \\
\hline & Business (reference alternative) & $4,7 \%$ \\
\hline \multirow{11}{*}{$\begin{array}{l}\text { Importance of the destination } \\
\text { attributes }(1-4)\end{array}$} & Cleaning and hygiene & 2,23 \\
\hline & Security & 2,17 \\
\hline & Climate & 2,34 \\
\hline & Total cost of the trip & 2,28 \\
\hline & Events and attractions & 1,79 \\
\hline & Transportation facilities & 1,87 \\
\hline & Commercial areas & 1,41 \\
\hline & Medical coverage & 1,77 \\
\hline & Places of historical interest & 2,52 \\
\hline & Natural landscapes & 2,34 \\
\hline & Distance & 1,74 \\
\hline \multirow[t]{2}{*}{ Accommodation typology } & Hotel & $70,9 \%$ \\
\hline & Apartment & $3,1 \%$ \\
\hline
\end{tabular}




\begin{tabular}{|l|l|c|}
\hline \multirow{5}{*}{ Traveling... } & Country house lodges & $1,4 \%$ \\
\cline { 2 - 3 } & Family / friend's house (reference alternative) & $17,4 \%$ \\
\cline { 2 - 3 } & Second residence & $70,9 \%$ \\
\hline \multirow{4}{*}{ Trip typology } & Alone & $10,9 \%$ \\
\cline { 2 - 3 } & Accompanied (reference alternative) & $89,1 \%$ \\
\hline \multirow{5}{*}{ Time spent (1-3) } & Fully independent travel (reference alternative) & $58,7 \%$ \\
\cline { 2 - 3 } & Package holidays & $20,1 \%$ \\
\cline { 2 - 3 } & IMSERSO & $21,2 \%$ \\
\hline & Shopping & 1,88 \\
\cline { 2 - 3 } & Organized day trips & 1,75 \\
\cline { 2 - 3 } & Visit to historical or artistic sights & 2,46 \\
\cline { 2 - 3 } & Physical activities & 1,23 \\
\cline { 2 - 3 } & Going to the theatre or cinema & 1,32 \\
\cline { 2 - 3 } & Visiting museums & 1,83 \\
\hline
\end{tabular}

The results of the determinant factors of the length of stay are presented in Table 3. They are globally significant according to the likelihood ratio $(\mathrm{p}<0.001)$, with an acceptable R-squared value for these types of models (Hensher and Johnson, 1981). However, it is interesting to note that the $\alpha$ parameter was significant at the 1 percent level, as its main implication is the invalidation of the basic assumption of equal mean and variance of the Poisson models, which favours the use of a Negative Binomial model (Cameron and Trivedi, 1998).

Table 3- Results of the determinant factors of the length of stay

\begin{tabular}{|l|c|c|c|}
\hline \multicolumn{1}{|c|}{ Variables } & Coefficient & Std. Error & Statistic \\
\hline C & 0.252 & 0.522 & 0.483 \\
\hline Age & $0.012^{\mathrm{b}}$ & 0.005 & 2.559 \\
\hline Gender: woman & 0.032 & 0.069 & 0.472 \\
\hline Self-perceived health & 0.012 & 0.053 & 0.235 \\
\hline Self-perceived economic status. & -0.013 & 0.054 & -0.243 \\
\hline Self-perceived time & 0.045 & 0.037 & 1.215 \\
\hline Holiday & 0.347 & 0.217 & 1.598 \\
\hline VFR (Visiting friends or relatives) & $0.625^{\mathrm{a}}$ & 0.216 & 2.894 \\
\hline Health & 0.333 & 0.278 & 1.197 \\
\hline National destination & -0.108 & 0.088 & -1.227 \\
\hline Cleaning and hygiene & 0.026 & 0.054 & 0.471 \\
\hline Security & -0.055 & 0.058 & -0.948 \\
\hline Climate & $0.073^{\mathrm{b}}$ & 0.032 & 2.308 \\
\hline Total cost of the trip & -0.045 & 0.036 & -1.265 \\
\hline Events and attractions & -0.006 & 0.043 & -0.148 \\
\hline Transportation facilities & 0.009 & 0.042 & 0.217 \\
\hline Commercial areas & -0.066 & 0.053 & -1.246 \\
\hline Medical coverage & 0.041 & 0.046 & 0.891 \\
\hline Places of historical interest & 0.027 & 0.041 & 0.664 \\
\hline Natural landscapes & -0.050 & 0.037 & -1.378 \\
\hline Distance & -0.042 & 0.041 & -1.033 \\
\hline Hotel & -0.159 & 0.126 & -1.269 \\
\hline Apartment & $0.643^{\mathrm{a}}$ & 0.220 & 2.927 \\
\hline Country house lodges & 0.117 & 0.321 & 0.365 \\
\hline Second residence & $0.892^{\mathrm{a}}$ & 0.149 & 5.980 \\
\hline Fully independent travel & $0.286^{\mathrm{a}}$ & 0.108 & 2.657 \\
\hline & & &
\end{tabular}




\begin{tabular}{|c|c|c|c|}
\hline Package holidays & 0.169 & 0.106 & 1.598 \\
\hline IMSERSO & $0.302^{a}$ & 0.112 & 2.699 \\
\hline Shopping & $0.128^{\mathrm{b}}$ & 0.051 & 2.493 \\
\hline Organized day trips & $0.103^{b}$ & 0.047 & 2.204 \\
\hline Visit to historical or artistic sights & -0.046 & 0.052 & -0.873 \\
\hline Physical activities & $0.203^{\mathrm{a}}$ & 0.062 & 3.292 \\
\hline Going to the theatre or cinema & 0.008 & 0.062 & 0.125 \\
\hline Visiting museums & 0.040 & 0.048 & 0.829 \\
\hline$\alpha$ & $-1.398^{\mathrm{a}}$ & 0.104 & -13.432 \\
\hline R-squared & $0.248^{\mathrm{a}}$ & & \\
\hline LR statistic (33 df) & $1576.3^{\mathrm{a}}$ & & \\
\hline
\end{tabular}

Regarding the results for each dimension Table 3, it can be concluded that the variables that determine the length of stay for Spanish seniors are age, 'VFR' motivation, the 'climate' attribute, accommodation in a holiday apartment and in a second residence, travelling alone, the 'IMSERSO' type of holiday, and certain activities carried out at the destination, such as shopping, organised day trips, and practising sports and physical activities.

With respect to H1, the relationship between the age variable and length of stay is positive and statistically significant, which means that the hypothesis can be accepted. This indicates that the greater the age, the longer the stay at the destination by the Spanish seniors analysed, thus corroborating the findings of Alegre and Pou (2003), Blazey (1992) Fleischer and Pizam (2002), Fleischer and Seiler (2002), Barros and Machado (2010), Barros et al (2010), Martínez-García and Raya (2008), Meng and Uysal (2008), Nicolau and Más (2009), Romsa and Blenman (1989) and Salmasi et al (2012). This finding could be related to the absence of time barriers for those seniors who are already retired and who therefore tend to undertake longer trips than those who are still active in the job market, in line with the findings of Blazey (1992), Fleischer and Pizam (2002), Fleischer and Seiler (2002), Romsa and Blenman (1989) and Salmasi et al (2012). However, hypothesis H2 is rejected, given the lack of significance between the sex variable and length of trip. The sex variable is not considered to influence the number of days Spanish seniors spend travelling, which contradicts the arguments of Barros and Machado (2010) and Meng and Uysal (2008).

With respect to the hypotheses related to the individual's domestic age, H3 and H4, which referred to the individual's life-cycle stage, the results obtained lead us to reject both hypotheses. Neither economic status, nor self-perceived available time, seem to be related to seniors' length of stay at their destination. This lack of a relationship could be justified by the complexity that characterises these two subjective variables, which are influenced, as noted by Cooper et al (2007), by others such as chronological age, the individual's employment situation and household type.

With respect to the two motivational dimensions, the reason for the trip (push factors) and the attributes of the destination (pull factors), the results obtained lead to the confirmation of the proposed 
hypotheses. So, regarding H5, the results show that the trips carried out by Spanish seniors in order to visit family members and/or friends had a significantly stronger effect on length of stay than the other proposed reasons for travelling (holidays, health and work), thus confirming previous findings by Jang et al (2003), Lawson (1991), Seaton and Palmer (1997), Wang (2005) and Wang et al (2008). The longer duration of these types of trips with respect to the others could be related to the type of accommodation used. Individuals who travel for this reason often stay overnight in family members' and/or friends' houses, and in this way keep available a larger budget for prolonging the stay at the destination. As for H6, the results only partially confirm it, since of the attributes preferred by seniors when choosing their destination, only one, climate, was found to significantly influence the duration of the trip. The relationship of the attribute 'climate' to length of stay is positive, and therefore matches the results obtained in this respect by Alegre and Pou (2003), Barros et al (2010) and Nicolau and Más (2009). This shows that those seniors who choose their destination based on the climate tend to enjoy longer stays. The lack of significance of the rest of the variables that comprise the appeal of the destination indicates that the number of days that Spanish seniors choose to spend at the destination is independent of the availability of basic services such as the hygiene and cleanliness of the place, its security, ease of transport, medical coverage or the availability of shopping centres; of resources related to nature and leisure events and attractions, places of historical/artistic interest, and natural landscapes; the distance from the individual's place of origin; and even the total cost of the trip.

Regarding the first hypothesis related to the trips's characteristics, which refers to the fact that the destination influences the length of stay, no relationship was found between both variables, which leads to H7 being rejected, against the conclusions by Wu and Carson (2008). Wu and Carson (2008) referred to the fact that foreign stays, in which a greater distance is usually covered, are longer. This is so because, as shown by Nicolau and Más (2009), tourists show greater predisposition to undertake longer journeys if they stay at the destination for a minimum number of days in order to compensate for the extra effort made in the journey, and to amortise the fixed costs associated with this type of journey. However, as shown above, distance does not have any effect on the length of stay. This could indicate that seniors are less sensitive to the distance to their destination than other groups when it comes to length of stay.

With regard to accommodation, H8 is confirmed, as both staying in a tourist apartment and at a second residence have a significant positive effect on length of stay, in agreement with the findings by Martínez-García and Raya (2008), Nicolau and Más (2006) and Salmasi et al (2012). These types of accommodation contribute to increase the number of vacation days spent by seniors at their destination. This is mainly for economic reasons, given the lower per capita daily cost involved in staying in an apartment. Amortising the holiday home in the case of a second home is also a relevant factor (Nicolau and Más, 2006). 
Similarly, the results obtained confirm H9, given that, as indicated by Alegre and Pou (2006), Lawson (1991) and Salmasi et al (2012), the size of group affects the length of stay. Specifically, it was found that those seniors who travel alone tend to have more extended stays at their destination than those who travelled with a companion, according to the results by Lawson (1991).

The type of trip also determined its length, which confirmed H10. Specifically, it was found that Spanish seniors who used IMSERSO for their trips stayed longer at their destination than those who travelled independently, or used any other type of organised trip. This was in contradiction with the findings of Bai et al (2001), who assured that seniors who travelled alone had longer stays than those who opted for a package holiday. However, it needs to be taken into account that the implementation of these types of trips, of which Spain was a pioneer, is still rare in other countries, and therefore it is not thought of as an alternative for many. Moreover, the longer duration of these types of trips in Spain, as opposed to those taken independently, and even compared with other types of organised trips, could be a result from the lack of flexibility that characterises IMSERSO programmes in terms of destination, time of year, and duration, which are established in advance. One of the aims of these programmes is to adjust seasonal tourism demand in those destinations which are overcrowded in high season, in order to maintain jobs and ensure the profitability of hotel infrastructures throughout the year. These infrastructures are then offered to groups that can travel at any time of the year and for a relatively extended period, as is the case for the majority of seniors.

Finally, the last of the hypotheses, H11, is accepted. It refers to the fact that, the larger the number of activities carried out at the destination, the longer the stay, which corroborates the findings by FerrerRosell et al (2014) and Lawson (1991). Specifically, it was found that the activities which contributed to increasing the length of stay at the destination of the Spanish seniors analysed were shopping, organised day trips and physical/sports activities.

\section{CONCLUSION AND IMPLICATIONS}

In this study an analysis of the determinant factors of the length of Spanish seniors' trips has been conducted, given their potential to have longer stays than other individuals, and the importance this has for the tourism industry. The results obtained from the analysis allow the acceptance of the majority of the proposed hypotheses. In particular, it was concluded that the length of stay at the destination is positively related to age, 'VFR' motivation, the 'climate' attribute of the destination, staying in a holiday apartment, staying in a second home, travelling alone, travelling with IMSERSO, and carrying out activities at the destination such as shopping, organised day trips, and physical/sports activities. The heterogeneity of seniors' behaviour in their role as consumers of goods and services was thus confirmed, as noted by Javalgi et al (1992), Schröder and Widmann (2007) and Wu (2003). 
Further, this heterogeneity of senior tourists' preferences has a theoretical implication when it comes to modelling their behaviour. The estimation of the Negative Binomial model made it possible to test the basic assumption of the equal mean and variance of the Poisson models. The results showed that the assumption was not fulfilled, making the Negative Binominal model more suitable than the Poisson model, as it avoids the potential bias of the estimates (Gurmu and Trivedi, 1996). In general terms, this result is further proof of the need to incorporate the existence of —not only explicit but also implicit—heterogeneity into the models that deal with tourist behaviour.

Additionally, these results have a number of implications for the sector. With respect to age, the fact that the length of stay increases as the individual ages implies that, based on the population projections referred to earlier, in the near future there will be a larger group of tourists who will contribute to the lengthening of stays at destinations. In this way, as posed by Alegre and Pou (2003), the aging of the population could halt the current trend towards shorter stays. The tourism industry therefore should promote longer trips amongst those segments of the elderly population who are probably already retired, given the fewer time restrictions that they have to face. The IMSERSO trips are an opportunity for the Spanish tourism industry, and the updating and improving of this type of programmes should be one of the main priorities of the Spanish public sector. As well as contributing to extending seniors' stay at their destination and adjusting seasonal tourism demand, the IMSERSO trips generate important profits for the State, as the income thus obtained is higher than the investment made, according to data from the study carried out by Price Waterhouse et al (1997).

In line with the above, it must also be noted that trips mainly motivated by visiting friends and/or family have an important impact to mitigate tourism seasonality (Seaton and Palmer, 1997). Taking into account that this type of trips tend to involve prolonged stays at the destination, special attention should be paid to those seniors who travel for this reason. In terms of the second motivational dimension, the attributes of the destination, it is deemed appropriate when promoting a destination to highlight the 'climate' attribute in those situations with agreeable climate, due to its positive effect on seniors' length of stay, rather than concentrating on other attributes such as price, distance, etc., which apparently have little effect on this group's the length of stay.

With regard to accommodation type, the sector should especially promote holiday apartments amongst the elderly population, as well as fomenting leisure activities aimed at this population group in those places with a large concentration of holiday homes and second residences, given the positive relationship that exists between these two types of accommodation and the length of stay by seniors. It needs to be noted that Spain does not only lead the ranking of primary home ownership, but is also one of the European countries with the largest percentage of holiday home ownership. This should be taken advantage of to try to promote longer stays by seniors who have this type of holiday home available. With respect to the size of the travelling group, there should be special emphasis on the 
design of trips for seniors who travel alone if the intention is to extend their stay at the destination. Finally, the length of stay by seniors will be increased if there is a wide and varied range of activities aimed specifically at this group, such as shopping, organised day trips, and physical/sports activities.

\section{Limitations of the study and future research lines}

The limitations of this study include, on the one hand, the limited predictive capacity of crosssectional studies, such as this one, as indicated by Wooldridge (2006); nevertheless, Wooldridge also noted that cross-sectional data are the most used in economics and other social sciences. With the aim of overcoming this limitation, a longitudinal study is proposed here. This type of focus has already been recommended by other authors (Huh, 2006; Wang, 2005) in the area of senior tourist behaviour due to its capacity to capture the changes related to travel behaviour over time when they are produced.

Additionally, our analysed sample does not allow the extrapolation of the results to seniors in other countries who, as has been demonstrated, may show a different behaviour in terms of length of stay according to the behavioural variables analysed, as shown in the study by Bai et al (2001) regarding the type of trip undertaken. It is considered to be appropriate to undertake an analysis of seniors from Spain's main client markets, such as the United Kingdom and Germany, countries which, along with Spain, have a high rate of aging population.

Finally, it would be advisable to focus on specific destinations to ascertain whether the effect of the analysed variables on the length of stay varies depending on the destination being considered.

\section{REFERENCES}

ALEGRE, J. y POU, LL. (2003), "La estancia media de los turistas en Islas Baleares: determinantes microeconómicos e implicaciones sobre la evolución del gasto agregado”, XII Simposio Internacional de Turismo y Ocio, ESADE, Barcelona.

ALEGRE, J. y POU, LL. (2006). "The length of stay in the demand for tourism", Tourism Management, 27, pp. 1343-1355.

ALEGRE, J., MATEO, S. y POU, LL. (2011). “A latent class approach to tourists' length of stay”, Tourism Management, 32, p. 555-563.

ALÉN, M.E., DOMÍNGUEZ, T. y FRAIZ, A. (2010). "El turismo senior como segmento de mercado emergente" Cuadernos de Turismo, 26, pp. 9-24.

BAI, B., JANG, S.S., CAI, L.A. y O'LEARY, J.T. (2001). "Determinants of travel mode choice of senior travelers to the United States” Journal of Hospitality \& Leisure Marketing, 8, 3/4, pp. 147-168.

BAI, B., SMITH, W., CAI, L.A. y O’LEARY, J. (1999). Senior sensitive segments: Looking at travel behavior. En K. S. Chon (Ed.), The Practice of Graduate Research in Hospitality and Tourism, (pp. 75-89). New York: The Haworth Hospitality Press.

BALOGLU, S. y UYSAL, M. (1996). "Market segments of push and pull motivations: a canonical correlation approach" International Journal of Contemporary Hospitality Management, 8, 3, pp. 3238. 
BARROS, C.P., BUTLER, R. y CORREIA, A. (2010). “A length of stay of golf tourism: A survival analysis”, Tourism Management, 31, pp. 13-21.

BARROS, C.P. y MACHADO, L.P. (2010). “The length of stay in tourism”, Annals of Tourism Research, 37 (3), pp. 692-706.

BATRA, A. (2009). "Senior pleasure tourists: examination of their demography, travel experience, and travel behavior upon visiting the Bangkok metropolis" International Journal of Hospitality \& Tourism Administration, 10, 3, pp. 197-212.

BLAZEY, M.A. (1992). “Travel and retirement status” Annals of Tourism Research, 19, 771-783.

CAMERON, A.C. and TRIVEDI, P.K. (1998) "Regression Analysis of Count Data", Nueva York: Cambridge University Press.

CHEN, H.W.J. (2009). Baby boomers' and Seniors' Domestic Travel Motivations: An examination of citizens in Tainan, Taiwan. Master Thesis. University of Waterloo. Canada.

COLLINS, D. y TISDELL, C. (2002). “Age-related lifecycles: purpose variations” Annals of Tourism Research, 29, 3, pp. 801-818.

COOPER, C., FLETCHER, J., FYALL, A.G.D. y WANHILL, S. (2007). El Turismo: teoría y práctica. Madrid: Síntesis.

CROMPTON, J.L. (1979). "Motivations for pleasure vacation” Annals of Tourism Research, 6, 4, pp. 408-424.

DELLAERT, B.G.C., ETTEMA, D.F. y LINDH, C. (1998). "Multi-faceted tourist travel decisions: a constraint-based conceptual framework to describe tourists' sequential choices of travel components" Tourism Management, 19, 4, 313-320.

FERRER-ROSELL, B., MARTÍNEZ-GARCÍA, E. y COENDERS, G. (2014). "Package and no-frills air carriers as moderators of length of stay ”, Tourism Management, 42, pp. 114-122.

FLEISCHER, A., PELEG, G. y RIVLIN, J. (2011). "The impact of changes in household vacation expenditures on the travel and hospitality industries”, Tourism Management, 32, pp. 815-821.

FLEISCHER, A. y PIZAM, A. (2002). “Tourism Constraints among Israeli Seniors” Annals of Tourism Research, 29, 1, pp. 106-123.

FLEISCHER, A. y SEILER, R. (2002). "Determinants of vacation travel among Israeli seniors: Theory and evidence” Applied Economics, 34, pp. 421-430.

GLOVER, P. y PRIDEAUX, B. (2008). "Using population projections to identify aspects of future tourism demand” Advances in Hospitality and Leisure, 4, pp. 185-209.

GOKOVALI, U., BAHAR, O. y KOZAK, M. (2007). "Determinants of length of stay: a practical use of survival analysis”, Tourism Management, 28, pp. 736-746.

GREENE, W.H. (2012). Econometric Analysis, Prentice Hall: Boston.

GRIGOLON, A.B., BORGERS, A.W.J., KEMPERMAN, A.D.A.M. y TIMMERMANS, H.J.P. (2014). "Vacation length choice: a dinamic mixed multinomial logit model", Tourism Management, 41, pp. 158-167.

HELLERSTEIN, D. and MENDELSOHN, R. (1993). "A Theoretical Foundation for Count Data Models”, American Journal of Agricultural Economics, 75, 3, 604-611.

HENSHER, D.A. and JOHNSON, L.W. (1981) Applied Discrete-Choice Modelling, Nueva York: John Wiley \& Sons, Inc.

HUANG, L. y TSAI, H. (2003). "The study of senior traveler behavior in Taiwan” Tourism Management, 24, 5, pp. 561-574.

HUH, C. (2006). A study of changes in patterns of travel behavior over time: a cohort analysis approach. Tesis Doctoral. Michigan State University. United States. 
IET (2010), Instituto de Estudios Turísticos. Encuesta de los Movimientos Turísticos de los Españoles (Familitur). Disponible en: http://www.iet.tourspain.es/esES/estadisticas/familitur/Anuales/Informe\%20anual\%20de\%20Familitur.\%20A\%C3\%B10\%202010.p $\underline{\mathrm{df}}$

IET (2012a), Instituto de Estudios Turísticos. Encuesta de los Movimientos Turísticos de los Españoles (Familitur). Disponible en: http://www.iet.tourspain.es/esES/estadisticas/familitur/Anuales/Informe\%20anual\%20de\%20Familitur.\%20A\%C3\%B10\%202012.p $\underline{\mathrm{df}}$

IET (2012b), Instituto de Estudios Turísticos. Encuesta de Gasto Turístico (Egatur), Movimientos Turísticos en Fronteras (Frontur). Disponible en: http://www.iet.tourspain.es/esES/estadisticas/frontur/Anuales/Movimientos\%20Tur\%C3\%ADsticos\%20en\%20Fronteras\%20(Front ur)\%20y\%20Encuesta\%20de\%20Gasto\%20Tur\%C3\%ADstico\%20(Egatur)\%202012.pdf

INE (2010). INEbase. Demografía y población. Padrón. Población por municipios. Disponible en: http://www.ine.es/jaxi/menu.do?type=pcaxis\&file=pcaxis\&path=\%2Ft20\%2Fe245\%2Fp04\%2F\%2Fa2010

JANG, S. (SHAWN) y WU, C.E. (2006). "Seniors' travel motivation and the influential factors: An examination of Taiwanese seniors” Tourism Management, 27, 2, pp. 306-316.

JANG, S., YU, L., y PEARSON, T. (2003). "Chinese travelers to the United States: A comparison of business travel and visiting friends and relatives” Tourism Geographies, 5, 1, pp. 87-108.

JAVALGI, R.G., THOMAS, E.G. y RAO, S.R. (1992). "Consumer behavior in the U.S. pleasure travel marketplace: An analysis of senior and nonsenior travelers” Journal of Travel Research, 31, 2, pp. 14-19.

LAWSON, R. (1991). "Patterns of Tourist Expenditure and Types of Vacation across the Family Life Cycle” Journal of Travel Research, 29, 4, 12-18.

LEE, B.D. (2005). Motives, behaviors, and attachments: a comparative study between older travelers and younger travelers in a national scenic area. Tesis Doctoral. The Pennsylvania State University. United States.

LITRELL, M.A., PAIGE, R.C. y SONG, K. (2004). "Senior travellers: tourism activates and shopping behaviours” Journal of Vacation Marketing, 10, 4, pp. 348-362.

MARTÍNEZ-GARCÍA, E. y RAYA, J.M. (2008). "Length of stay for low-cost tourism”, Tourism Management, 29, pp. 1064-1075.

MENG, F. y UYSAL, M. (2008). "Effects of gender differences on perceptions of destination attributes, motivations and travel values: an examination of a nature-based resort destination”, Journal of Sustainable Tourism, 16, 4, pp. 445-466.

MONIRUZZAMAN, M., PÁEZ, A., HABIB, K.M.N. y MORENCY, C. (2013). "Mode use and trip length of seniors in Montreal”, Journal of Transport Geography, 30, pp. 89-99.

NICOLAU, J.L. y MÁS, F.J. (2006). “Elección de la duración del viaje vacacional: una aproximación con modelos de recuento”, Revista Europea de Dirección y Economía de la Empresa, 15, 2, pp. 99116.

NICOLAU, J.L., y MÁS, F.J. (2009). "Simultaneous analysis of whether and how long to go on holidays” The Service Industries Journal, 29, 8, 1077-1092.

NORMAN, W.C., DANIELS, M.J., MCGUIRE, F. y NORMAN, C.A. (2001). "Wither the mature market: An empirical examination of the travel motivations of neo-mature and veteran-mature markets” Journal of Hospitality \& Leisure Marketing, 8, 3/4, pp. 113-130.

OPPERMANN, M. (1995). "Family life cycle and cohort effects: a study of travel patterns of German residents” Journal of Travel \& Tourism Marketing, 4, 1, 23-44.

PATTERSON, I. (2006). Growing older. Tourism and leisure behaviour of older adults. Cambridge: Cabi. 
PEYPOCH, N., RANDRIAMBOARISON, R., RASOAMANANJARA, F. y SOLONANDRASANA, B. (2012). "The length of stay of tourists in Madagascar", Tourism Management, 33, pp. 1230-1235.

PLOG, S. C. (2005). Targeting segments: more important than ever in the travel industry. En W. F. Theobald (Ed.), Global Tourism (3 ${ }^{\mathrm{a}}$ ed.), pp. 271-293. Boston: Butterworth-Heinemann.

PRAYAG, G. (2012). "Senior Travelers' Motivations and Future Behavioral Intentions: The case of Nice”,Journal of Travel \& Tourism Marketing, 29, 7, pp. 665-681.

PRICE WATERHOUSE, MUNDO SOCIAL, AECA, ZONTUR, ANET, EMER-GFK, IMSERSO (1997). Incidencia socioeconómica de los programas de vacaciones para mayores y termalismo social del IMSERSO. Madrid: Instituto de Migraciones y Servicios Sociales.

PRIDEAUX, B., WEI, S. y RUYS, H. (2001). “The senior drive tour market in Australia” Journal of Vacation Marketing, 7, 3, pp. 209-219.

RAMOS, I. (2005). El estilo de vida de las personas mayores y la comunicación publicitaria. Un análisis empírico. Tesis doctoral. Universidad de Alicante. España.

ROMSA, G. y BLENMAN, M. (1989). "Vacation Patterns of the Elderly German” Annals of Tourism Research, 16, 2, pp. 178-188.

RYAN, C. (1995). "Learning about tourists from conversations: the over-55s in Majorca” Tourism Management, 16, 3, pp. 207-215.

SANGPIKUL, A. (2008). "Travel motivations of Japanese senior travellers to Thailand” International Journal of Tourism Research, 10, pp. 81-94.

SCHRÖDER, A. y WIDMANN, T. (2007). Demographic Change and its impact on the travel industry: Oldies-nothing but goldies? En R. Conrady y M. Buck (Eds.), Trends and issues in Global Tourism, (pp. 3-17). Berlín: Springer.

SEATON, A.V., y PALMER, C. (1997). "Understanding VFR tourism behaviour: the first five years of the United Kingdom tourism survey”, Tourism Management, 18, 6, pp. 345-355.

SALMASI, L., CELIDONI, M. y PROCIDANO, I. (2012). "Length of stay: Price and income semielasticities at different destinations in Italy", International Journal of Tourism Research, 14, pp. 515530 .

UNITED NATIONS (2013). World Population Ageing, Population Division, http://www.un.org/en/development/desa/population/publications/pdf/ageing/WorldPopulationAgeingR eport2013.pdf

UNWTO (2010). Demographic Change and Tourism. Madrid.

WANG, Y. (2005). An exploratory study of travel constructs in mature tourism. Tesis Doctoral. Clemson University. South Carolina. United States.

WANG, Y., ZHANG, Y., XIA, J. y WANG, Z. (2008). "Segmenting the mature travel market by motivation”, International Journal of Data Analysis Techniques and Strategies, 1, 2, pp. 193-209.

WOOLDRIDGE, J. M. (2006). Introducción a la econometría: un enfoque moderno (2a ed.). Madrid: Thomson Learning.

WU, C.M.E. (2003). An exploratory study of taiwanese seniors' travel motivations and travel behavior. Tesis Doctoral. Kansas State University. United States.

WU, C.L., y CARSON, D. (2008). "Spatial and temporal tourist dispersal analysis in multiple destination travel”, Journal of Travel Research, 46, pp. 311-317. 